\title{
Molecular Dynamics Simulation of the High Lithium Ion Conductor, $\mathrm{La}_{0.6} \mathrm{Li}_{0.2} \mathrm{TiO}_{3}$
}

\author{
Tetsuhiro KATSUMATA, Yoshiyuki INAGUMA, Mitsuru ITOH ${ }^{\dagger}$ and Katsuyuki KAWAMURA* \\ Materials and Structures Laboratory, Tokyo Institute of Technology, 4259, Nagatsuta, Midori-ku, Yokohama-shi 226-8503 \\ *Faculty of Science, Tokyo Institute of Technology, 2-12-1, Ookayama, Meguro-ku, Tokyo 152-8551
}

\author{
高リチウムイオン伝導体, $\mathrm{La}_{0.6} \mathrm{Li}_{0.2} \mathrm{TiO}_{3}$ の分子動力学シミュレーション \\ 勝又哲裕・稲熊宜之・伊藤 満†河村雄行* \\ 東京工業大学応用セラミックス研究所, 226-8503 神奈川県横浜市緑区長津田町 4259 \\ *東京工業大学理学部地球惑星科学科, 152-8551 東京都目黒区大岡山 2-12-1
}

\begin{abstract}
Molecular dynamies (MD) simulation was carried out on the high $\mathrm{Li}$ ion conductor, $\mathrm{La}_{0.6} \mathrm{Li}_{0.2} \mathrm{TiO}_{3}$, using the partially ionic model (PIM). MD simulation of the Li ion conductivity with the variation of mobile ion size under high pressure revealed that this compound had the optimum lattice size for Li ion conduction and that the skeletal lattice was too small for $\mathrm{Li}^{+}$ion to show the highest conductivity.
\end{abstract}

[Received February 26, 1999; Accepted April 22, 1999]

Key-words : Perovskite-type oxide, $\mathrm{La}_{0.6} \mathrm{Li}_{0.2} \mathrm{TiO}_{3}$, High Li ion conductor, Molecular dynamics simulation, Partially ionic model, Bond covalence, Optimum lattice size

1. Introduction

In recent years, many solid $\mathrm{Li}$ ion conductors have been developed for their potential application in solid state devices, mainly as solid electrolytes in rechargeable $\mathrm{Li}$ ion batteries. In some solid ion conductors, Li ion conductivity has been as high as $10^{-3} \mathrm{~S} \cdot \mathrm{cm}^{-1}$ at room temperature. ${ }^{1)-7)}$ However, this value was lower than about $1 / 10$ that of the liquid electrolytes, and in order to use these conductors as solid electrolytes we have to improve their ionic conductivity. The perovskite-type $\mathrm{Li}$ ion conductor, $\mathrm{La}_{2 / 3-x} \mathrm{Li}_{3 x} \mathrm{TiO}_{3}$, is one of these promising fast $\mathrm{Li}$ ion conductors. $\mathrm{La}_{2 / 3-x} \mathrm{Li}_{3 x}$ $\mathrm{TiO}_{3}$ has a cation deficient perovskite structure in which $\mathrm{Li}$, $\mathrm{La}$, and a vacancy are distributed in the A-site, as shown in Fig. 1. In this study, the bottleneck is defined as the $3 c$ site with the space group $P m 3 m$ surrounded by four oxide ions in the structure. Ion migration is known to occur through the conduction path composed of $\mathrm{Li}$ ions and the vacancy. According to previous studies, $\mathrm{Li}$ ion conduction depends on the vacancy and carrier concentration. ${ }^{8)} \mathrm{La}_{0.55} \mathrm{Li}_{0.35} \mathrm{TiO}_{3}$, whose vacancy and carrier concentration are optimized, shows $\mathrm{Li}$ in conduction of $1.1 \times 10^{-3} \mathrm{~S} \cdot \mathrm{cm}^{-1}$ at room temperature.7) Several investigations of the transport mechanism of the perovskite-type $\mathrm{Li}$ ion conductors such as this compound have been carried out because of its simple structure and the high $\mathrm{Li}$ ion conductivity. $\left.{ }^{4)}-21\right)$ However the relationship between the lattice size and $\mathrm{Li}$ ion conductivity has not been understood completely.

In $\mathrm{Ln}_{0.5} \mathrm{Li}_{0.5} \mathrm{TiO}_{3}(\mathrm{Ln}=\mathrm{La}, \mathrm{Pr}, \mathrm{Nd}$, and $\mathrm{Sm})$, conductivity decreases with the average ionic radius of the A-site ion ${ }^{11)}$ and the pressure. ${ }^{12,13)}$ These results are considered to be caused by the contraction of the bottleneck due to the pressure or the substitution of the A-site ion. However, in $(1-x) \mathrm{La}_{0.55} \mathrm{Li}_{0.35} \mathrm{TiO}_{3-x} \mathrm{ATiO}_{3}(\mathrm{~A}=\mathrm{Sr}, \mathrm{Ba}$ and $\mathrm{Pb}), \mathrm{Li}$ ion conductivity did not always increase with $x$, while the lattice parameter always increased with $x$. In $(1-x) \mathrm{La}_{0.55} \mathrm{Li}_{0.35}$ $\mathrm{TiO}_{3-x} \mathrm{BaTiO}_{3}$, Li ion conductivity decreases continuously with $x$ and in $(1-x) \mathrm{La}_{0.55} \mathrm{Li}_{0.35} \mathrm{TiO}_{3-x} \mathrm{ATiO}_{3}(\mathrm{~A}=\mathrm{Sr}$ and $\mathrm{Pb}), \mathrm{Li}$ ion conductivity showed the maximum when the lattice parameter was about $0.388 \mathrm{~nm} .{ }^{7), 9)}$ The authors suggested that the decrease in $\mathrm{Li}$ ion conductivity in these solid

\footnotetext{
${ }^{\dagger}$ Author to whom correspondence should be addressed.
}

solutions was due to the local distortion of the crystal structure caused by the ion substitution. On the other hand, in $\mathrm{Li}^{+} \beta-\mathrm{Al}_{2} \mathrm{O}_{3}$ a decrease in the ion conductivity due to the lattice expansion has been observed. ${ }^{22)}$ It is noted that the ion conductivity of $\mathrm{Li}^{+} \beta-\mathrm{Al}_{2} \mathrm{O}_{3}$ was lower than that of $\mathrm{Na}^{+} \beta$ $\mathrm{Al}_{2} \mathrm{O}_{3}$ and $\mathrm{Ag}^{+} \beta-\mathrm{Al}_{2} \mathrm{O}_{3}$ under ambient pressure, even though the width of the conduction plane was almost the same in all the compounds. Furthermore, the ion conductivity of $\mathrm{Li}^{+} \beta-\mathrm{Al}_{2} \mathrm{O}_{3}$ increased with pressure, while that of $\mathrm{Na}^{+}$ $\beta-\mathrm{Al}_{2} \mathrm{O}_{3}$ and $\mathrm{K}^{+} \beta-\mathrm{Al}_{2} \mathrm{O}_{3}$ decreased with pressure. ${ }^{23), 24)}$ These results indicate that the lattice size of $\beta-\mathrm{Al}_{2} \mathrm{O}_{3}$ under ambient pressure is too large for $\mathrm{Li}$ ion conduction and that

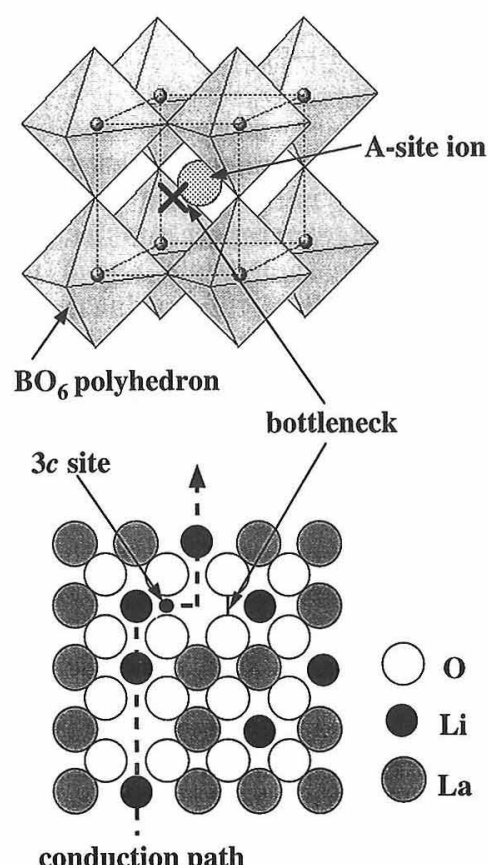

Fig. 1. Schematic figure of perovskite structure and shematic representation of the arrangement of A-site and oxide ions projected on $\{100\}$. 
it is suitable for $\mathrm{Li}$ ion conduction by the pressure. Therefore, $\mathrm{La}_{2 / 3-x} \mathrm{Li}_{3 x} \mathrm{TiO}_{3}$ may also have a lattice size suitable for $\mathrm{Li}$ ion conduction, and in $(1-x) \mathrm{La}_{0.55} \mathrm{Li}_{0.35}$ $\mathrm{TiO}_{3-x} \mathrm{ATiO}_{3}(\mathrm{~A}=\mathrm{Sr}, \mathrm{Ba}$ and $\mathrm{Pb})$ the large framework due to the lattice expansion may cause the decrease in $\mathrm{Li}$ ion conductivity. However, it is difficult to research the relationship between $\mathrm{Li}$ ion conduction and lattice size by ion substitution because other factors that influence $\mathrm{Li}$ ion conduction such as carrier concentration and bond character were simultaneously varied with the substitution of ions. If we can estimate the suitable lattice size and $\mathrm{Li}$ ion conductivity in the optimized structure, it would be useful in the design of novel fast ion conductors.

Molecular dynamics (MD) simulation can be used to investigate the relationship between ion migration and structural or chemical factors (bond covalence, lattice size, mobile ion size, etc.) because it allows us to change such factors independently and to explore ion dynamics at the atomic level under variable conditions. In the present study, we observed the motion of ions, mainly the $\mathrm{Li}$ ion, in $\mathrm{La}_{0.6}$ $\mathrm{Li}_{0.2} \mathrm{TiO}_{3}$ using $\mathrm{MD}$ simulation and will discuss the relationship between the bottleneck size and the ion migration. This paper follows the following organization: In Section 2, we will describe the systems, methods, conditions, and potential parameters used in the present simulation and experimental procedures. In Section 3, we will present the results and discuss the following issues: (1) the reproducibility of the physical properties in MD simulation using the partially ionic model (PIM), ${ }^{25)}$ (2) the influence of lattice size on $\mathrm{Li}$ ion migration as obtained from the MD simulation (by changing $\mathrm{Li}$ ion size under various pressures), and (3) the estimation of the optimum lattice size and $\mathrm{Li}$ ion conductivity in the optimized structure. Finally, the conclusions from the present work are described.

\section{Simulation and experimental procedures}

The interatomic potential of PIM is expressed by ${ }^{25)}$

$$
\begin{aligned}
U_{\mathrm{ij}}= & \frac{z_{\mathrm{i}} z_{\mathrm{j}} e^{2}}{r_{\mathrm{ij}}}+f_{0}\left(b_{\mathrm{i}}+b_{\mathrm{j}}\right) \exp \left[\frac{\left(a_{\mathrm{i}}+a_{\mathrm{j}}-r_{\mathrm{ij}}\right)}{\left(b_{\mathrm{i}}+b_{\mathrm{j}}\right)}\right]-\frac{c_{\mathrm{i}} c_{\mathrm{j}}}{r_{\mathrm{ij}}{ }^{6}} \\
& +D_{\mathrm{ij}}\left\{\exp \left[-2 \beta_{\mathrm{ij}}\left(r_{\mathrm{ij}}-r_{\mathrm{ij}}{ }^{*}\right)\right]\right. \\
& \left.-2 \exp \left[-\beta_{\mathrm{ij}}\left(r_{\mathrm{ij}}-r_{\mathrm{ij}}{ }^{*}\right)\right]\right\} .
\end{aligned}
$$

The first term in Eq. (1) represents the Coulomb interaction where $z_{\mathrm{i}}$ and $z_{\mathrm{j}}$ are the effective charges of the ions $i$ and $\mathrm{j}$, respectively, and $r_{\mathrm{ij}}$ is the interatomic distance between the ions. The second term represents the short-range repulsion potential. The parameters $a_{\mathrm{i}}$ and $a_{\mathrm{j}}$ reflect the ionic radii, and $b_{\mathrm{i}}$ and $b_{\mathrm{j}}$ reflect the hardness of the ions. The quantity $f_{0}$ is a constant $6.9478 \times 10^{-11} \mathrm{~N}$. The third term represents the dipole-induced dipole dispersion potential based on the Van der Waals interaction. The specific parameters of each ion, $a_{\mathrm{i}}, b_{\mathrm{i}}$, and $c_{\mathrm{i}}$, were determined by the trial and error method. The last term in the PIM represents the Morse potential which relates to the covalent bond. Here the bond directionality is ignored. $D_{\mathrm{ij}}, \beta_{\mathrm{ij}}$, and $r_{\mathrm{ij}}{ }^{*}$ are the specific parameters of the bond between the $i$ and $j$ ions. In the PIM, the effective charge of ions influenced by the bond covalency is reduced from the nominal ionic valence. In the preset study $z_{\mathrm{Ti}}$ determined from the previous studies on $\mathrm{SrTiO}_{3}$ and $\mathrm{TiO}_{2}$, which have almost the same Ti-O bond length as $\mathrm{La}_{0.6} \mathrm{Li}_{0.2} \mathrm{TiO}_{3}$. According to the angle integrate photoemission experiment ${ }^{26)}$ and the band calculation based on the augment plane wave method for $\mathrm{SrTiO}_{3},{ }^{27)}$ the number of $d$ electrons in Ti ion was estimated to about +1.5 , that is, the effective charge of $\mathrm{Ti}$ ion is +2.5. Furthermore the MD simulation for $\mathrm{TiO}_{2}$ polymor-

\begin{tabular}{|c|c|c|c|c|c|}
\hline Ion & $\begin{array}{c}\text { The number } \\
\text { of ions }\end{array}$ & $z(\mathbf{e})$ & $a(\mathrm{~nm})$ & $b(\mathrm{~nm})$ & $\begin{array}{c}c \times 10^{3} \\
\left(\mathrm{~kJ}^{1 / 2} \cdot \mathrm{nm}^{3} \cdot \mathrm{mol}^{-1 / 2}\right)\end{array}$ \\
\hline o & 540 & -1.267 & 0.19265 & 0.018 & 84 \\
\hline $\mathbf{T i}$ & 180 & +2.400 & 0.11158 & 0.010 & 0 \\
\hline $\mathbf{L a}$ & 108 & +2.000 & 0.17070 & 0.010 & 29 \\
\hline $\mathbf{L i}$ & 36 & +1.000 & 0.10010 & 0.008 & 8 \\
\hline \multicolumn{2}{|c|}{ Ion pair } & $D(\mathbf{k J} \cdot \mathbf{m o l}$ & & $8\left(\mathrm{~nm}^{-1}\right)$ & $r^{*}(\mathrm{~nm})$ \\
\hline \multicolumn{2}{|c|}{ Ti-O } & 260 & & 20 & 0.188 \\
\hline
\end{tabular}
phs (brookite, anatase and rutile) reproduced its physical
Table 1. Potential Parameters of Each Ion and Ion Pair for PIM

properties and structures well when the $z_{\mathrm{Ti}}$ and $z_{\mathrm{O}}$ was +2.4 and -1.2 , respectively. ${ }^{28)}$ Therefore $z_{\mathrm{Ti}}$ in this system was reduced to +1.2 from +4.0 . Since the ionicity of the $\mathrm{La}-\mathrm{O}$ bond calculated from the difference of electron negativities between $\mathrm{O}$ and $\mathrm{La}$ ions is about 75 percent, ${ }^{29)}$ the $z_{\mathrm{La}}$ was also reduced to +2.0 from +3.0 . The $z_{\mathrm{Li}}$ was constant, the normal valence being +1.0 . The $z_{0}$ was determined at -1.274 to keep the charge neutralization in the system. Other potential parameters were determined by the trial and error method to reproduce the compressibility, thermal expansion and structure at room temperature. All the parameters are listed in Table 1.

$\mathrm{La}, \mathrm{Li}$ and vacancy were distributed randomly in A-sites in the simulation cell which has 864 particles. The number of each ions are also shown in Table 1 . The simulations were carried out using the program, MXDORTO developed by Kawamura ${ }^{30}$ in which a rapid convergence was achieved by the Ewald method. The Verlet algorithm was applied for the atomic motions. Periodic boundary conditions were used with the MD basic cell. All the simulations were carried out under constant temperature and pressure, which were controlled by the scaling of particle velocities and basic cell parameters, respectively. A period of one simulation was $200 \mathrm{ps}$ ( 100000 steps) at $2 \mathrm{fs}$ time steps. The diffusion coefficient of the lithium ion, $D^{\mathrm{Li}}$, was calculated from the time dependence of the mean square displacement (MSD), $\left\langle\Delta r(t)^{2}\right\rangle$, using the Einstein relation

$$
\left\langle\Delta r(t)^{2}\right\rangle=A+6 D_{t}^{\mathrm{Li}}
$$

where $A$ is a constant. Lithium ion conductivity, $\sigma$, was calculated from $D^{\mathrm{Li}}$ using the Nernst-Einstein equation. The pair correlation function is expressed as the following equation,

$$
g_{\mathrm{ij}}(r)=\sum_{\mathrm{j}}^{N_{\mathrm{j}}} \frac{n_{\mathrm{ij}}(r-\Delta r / 2 ; r+\Delta r / 2)}{4 \pi\left(N_{\mathrm{i}} N_{\mathrm{j}} / V\right) r^{2} \Delta r}
$$

where $V$ is the volume of a unit cell and $N_{\mathrm{i}}$ and $N_{\mathrm{j}}$ is the number of ions $\mathrm{i}$ and $\mathrm{j}$ in a unit cell, respectively. The $n_{\mathrm{ij}}$ is the number of ion $\mathrm{j}$ in the area between sphere 1 (its radius is $r-\Delta r$ ) and sphere 2 (its radius is $r+\Delta r$ ), whose center is ion i. In this study, $\Delta r$ is $0.001 \mathrm{~nm}$.

The $\mathrm{La}_{0.6} \mathrm{Li}_{0.2} \mathrm{TiO}_{3}$ polycrystalline sample for the investigation of physical properties and structure was prepared by the conventional solid state reaction technique. Powders of $\mathrm{La}_{2} \mathrm{O}_{3}(99.9 \%), \mathrm{Li}_{2} \mathrm{CO}_{3}(99.9 \%)$ and $\mathrm{TiO}_{2}$ $(99.9 \%)$ were used as the starting materials. The mixture was calcined at $1373 \mathrm{~K}$ for $12 \mathrm{~h}$, sintered at $1423 \mathrm{~K}$ for $5 \mathrm{~h}$ in air, and quenched to room temperature so that the arrangement of lanthanum ions was in the disordered state. Thermal expansion was measured using a high temperature $\mathrm{X}$-ray diffractometer (Mac Science $\mathrm{MPX}^{18} \mathrm{X}$-ray diffractometer) from $300 \mathrm{~K}$ to $1200 \mathrm{~K}$. Both sides of the sample were pasted with gold as electrode, and $\mathrm{Li}$ ion conductivity was measured in the temperature range from $238 \mathrm{~K}$ to 625 $\mathrm{K}$ by the ac impedance method using a HP 4192 impedance analyzer in the frequency range $5 \mathrm{~Hz}-13 \mathrm{MHz}$. 


\section{Results and discussions}

3.1 Reproducibility of physical properties in MD simulation using PIM

Table 2 shows the structural data of $\mathrm{La}_{0.6} \mathrm{Li}_{0.2} \mathrm{TiO}_{3}$ obtained by $\mathrm{MD}$ simulation and experiment at $300 \mathrm{~K}$. The lattice parameter (cube root of volume of perovskite unit cell), $a_{\mathrm{p}}$, and density, $d$, obtained by MD simulation was in accord with experimental value. In this simulation, the $a, b$, and $c$ parameters were same within thermal fluctuations. The MD simulation could reproduce the cubic structure of actual $\mathrm{La}_{0.6} \mathrm{Li}_{0.2} \mathrm{TiO}_{3}$ at $300 \mathrm{~K}$.

Figure 2 shows the temperature variation of the density of $\mathrm{La}_{0.6} \mathrm{Li}_{0.2} \mathrm{TiO}_{3}$ in the experiment and the simulation using the PIM. The bulk thermal expansion coefficients, $\alpha$, determined by the simulation and experiment were $3.09 \times 10^{-5}$ and $2.66 \times 10^{-5}$, respectively. The $\alpha$ obtained by the PIM was in good agreement with experimental one.

Figure 3 shows the volume change of $\mathrm{La}_{0.6} \mathrm{Li}_{0.2} \mathrm{TiO}_{3}$ under hydrostatic pressure calculated by the $\mathrm{MD}$ simulation with the experimental data of $\mathrm{SrTiO}_{3} .{ }^{31}$ ) The compressibility of $\mathrm{La}_{0.6} \mathrm{Li}_{0.2} \mathrm{TiO}_{3}$ obtained from the MD simulation is considered to be comparable to that of $\mathrm{SrTiO}_{3}$, though the compressibility, $\kappa$, of $\mathrm{La}_{0.6} \mathrm{Li}_{0.2} \mathrm{TiO}_{3}$ is unknown (Because the compressibility of perovskite titanates are

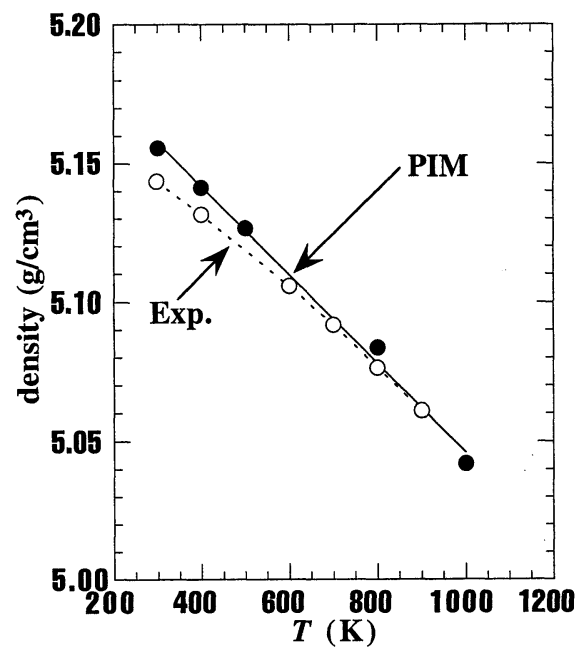

Fig. 2. Temperature dependence of $\mathrm{La}_{0.6} \mathrm{Li}_{0.2} \mathrm{TiO}_{3}$ density obtained by the simulation and experiment.

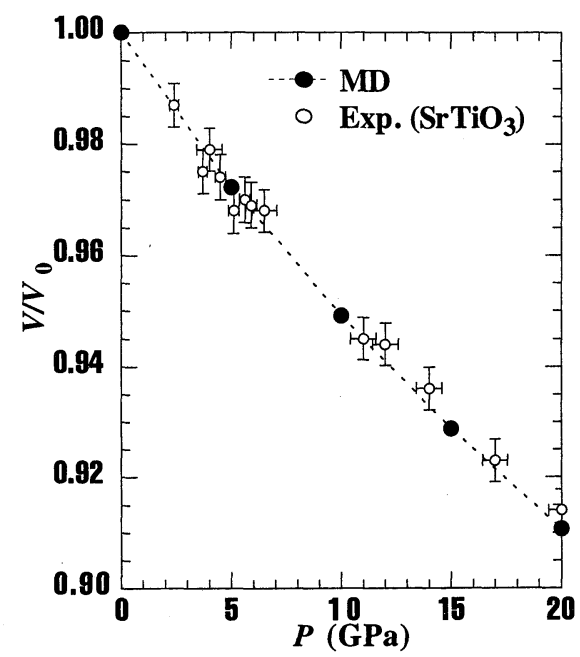

Fig. 3. Pressure dependence of $\mathrm{La}_{0.6} \mathrm{Li}_{0.2} \mathrm{TiO}_{3}$ volume obtained by simulation and experiment for $\mathrm{SrTiO}_{3}$. almost the same, i.e., $5.68 \times 10^{-12} \mathrm{~Pa}^{-1}$ for $\mathrm{SrTiO}_{3}$ and $7.8 \times 10^{-12} \mathrm{~Pa}^{-1}$ for $\left.\mathrm{BaTiO}_{3}\right) .31$ ) The initial compressibility, $\kappa$, which was obtained by the extrapolation of the linear part of the data in the low pressure region, was $6.06 \times 10^{-12}$ $\mathrm{Pa}^{-1}$. The result in $\mathrm{MD}$ simulation shows good agreement with the experimental one of $\mathrm{SrTiO}_{3}$. Therefore thermal expansion, compressibility, and crystal structure at room temperature were reproduced in this simulation using the PIM.

Since $\mathrm{Li}$ ion motion is most interesting in this simulation, we observed $\mathrm{Li}$ ion motion by the trajection plot. Figure 4 shows the trajection plots of $\mathrm{Li}, \mathrm{O}$ and $\mathrm{La}$ ions at $300 \mathrm{~K}$. At $300 \mathrm{~K}$ the $\mathrm{Li}$ ions were found to migrate from A-site to adjacent A-site through the bottleneck. Furthermore, we calculated the pair correlation function to investigate the distribution of ions. Figure 5 shows $g_{\mathrm{Ti}-\mathrm{Ti}}(r), g_{\mathrm{Ti}-0}(r)$,

Table 2. Crystal Structure Obtained by MD Simulation and Experiment

\begin{tabular}{ccc}
\hline & PIM & Exp. \\
\hline$a_{\mathrm{p}} / \mathrm{nm}$ & $0.387(8)$ & $0.38777(2)$ \\
$a / \mathrm{nm}$ & $0.390(8)$ & - \\
$b / \mathrm{nm}$ & $0.385(6)$ & - \\
$c / \mathrm{nm}$ & $0.387(7)$ & - \\
$d / \mathrm{g}^{\circ} \mathrm{cm}^{-3}$ & $5.147(4)$ & $5.1436(9)$ \\
\hline
\end{tabular}

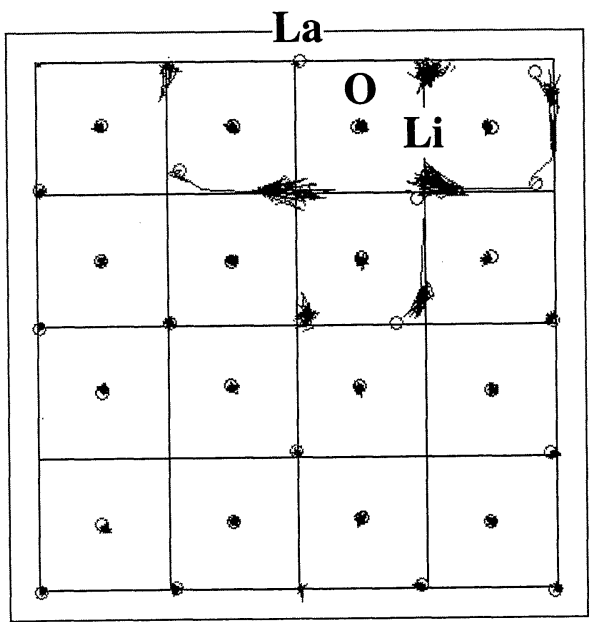

Fig. 4. Trajectory plots of $\mathrm{Li}, \mathrm{La}$ and $\mathrm{O}$ ions projected on $\{100\}$ plane for $\mathrm{La}_{0.6} \mathrm{Li}_{0.2} \mathrm{TiO}_{3}$ at $300 \mathrm{~K}$.

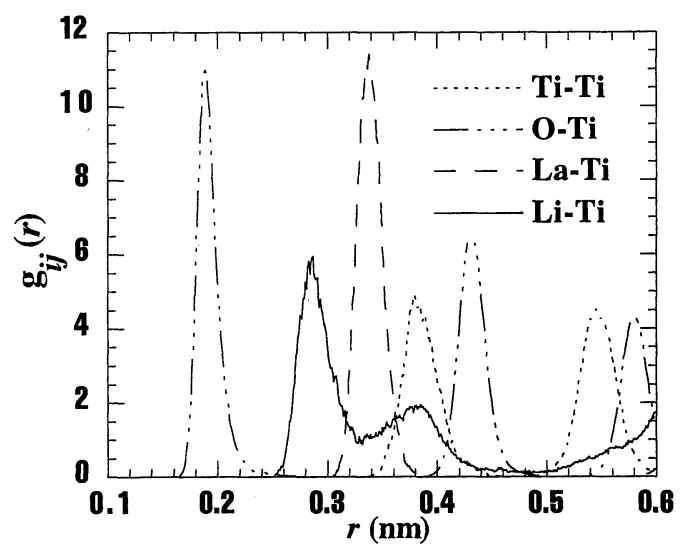

Fig. 5. Pair correlation function for ion pairs, Ti-Ti, O-Ti, La$\mathrm{Ti}$, and $\mathrm{Li}-\mathrm{Ti}$, at $300 \mathrm{~K}$. 
$g_{\mathrm{Ti}-\mathrm{La}}(r)$ and $g_{\mathrm{Ti- \textrm {Li }}}(r)$ at $300 \mathrm{~K}$. While the $g_{\mathrm{Ti}-\mathrm{Ti}}(r), g_{\mathrm{Ti}-0}(r)$ and $g_{\mathrm{Ti}-\mathrm{La}}(r)$ showed clear peaks at the distance between each equivalent position, the peaks of the $g_{\mathrm{Ti}-\mathrm{Li}}(r)$ were connected. The $g_{\mathrm{Ti}-\mathrm{Li}}(r)$ begin to increase at $r=0.25$ and is not zero at every $r$ value in $r>0.25$. Since the distance between the bottleneck and the Ti ion is $0.27 \mathrm{~nm}, \mathrm{Li}$ ions are found to exist at various positions between the A-site and bottleneck and are indicated to migrate in this simulation cell.

Figure 6 shows the time dependence mean square displacement (MSD) of $\mathrm{La}, \mathrm{Ti}, \mathrm{O}$ and $\mathrm{Li}$ ions at $300 \mathrm{~K}$. While each MSD of the La, Ti and O ions showed no time dependence, that of $\mathrm{Li}$ ion increased with time. The $\mathrm{Li}$ ion apparently diffused at $300 \mathrm{~K}$ in this simulation. The curvature of the time dependence MSD is found to be due to the simulation condition.

Table 3 shows the $D^{\mathrm{Li}}$ at $300 \mathrm{~K}, 500 \mathrm{~K}$ and $1000 \mathrm{~K}$ estimated in each MD simulation for three simulation cells with different arrangements of A-site ions and obtained by the experiment. As shown in this table, the $D^{\mathrm{Li}}$ obtained by MD simulation was smaller than that obtained by experiment at each temperature. The difference in among the three simulation cells was larger at low temperatures and decreased with the increase in temperature. The large difference in $D^{\mathrm{Li}}$ among the three simulation is mainly attributed to the simulation condition, since the difference in $D^{\mathrm{Li}}$ decreased with increasing temperature. At low temperature the precise $D^{\mathrm{Li}}$ could not be estimated under this simulation condition owing to an insufficient number of particles and/or simulation steps, but at high temperature the precise $D^{\mathrm{Li}}$ could be estimated under this condition because of increasing the $D^{\mathrm{Li}}$ with increasing temperature. Though the arrangement of A-site ions may influence ion diffusion, the precision of $D^{\mathrm{Li}}$ in this simulation is not enough to evaluate the influence. Accordingly, we consider that the difference between the experiment and the MD simulation at low temperatures is caused by the insufficient number of particles and/or simulation steps, and the $D^{\mathrm{Li}} \mathrm{ob}-$ tained at high temperatures $(\geq 500 \mathrm{~K})$ can be used for the

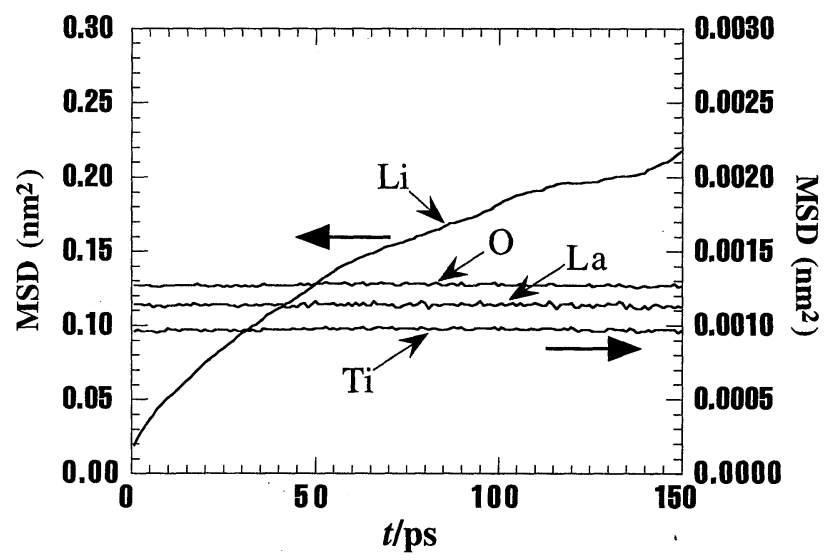

Fig. 6. Time dependence of the mean square displacement (MSD) of $\mathrm{La}, \mathrm{Li}, \mathrm{Ti}$ and $\mathrm{O}$ ions at $300 \mathrm{~K}$.

Table 3. Diffusion Coefficients of $\mathrm{Li}$ Ion on MD Simulation and Experiment at $300 \mathrm{~K}, 500 \mathrm{~K}$ and $1000 \mathrm{~K}$

\begin{tabular}{ccccc}
\hline \multirow{5}{*}{$T(\mathrm{~K})$} & \multicolumn{4}{c}{ Diffusion coefficient $\left(\mathrm{cm}^{2} \cdot \mathrm{s}^{-1}\right)$} \\
& Configuration A & Configuration B & Configuration C & Exp. \\
\hline 300 & $1.4(9) \times 10^{-9}$ & $1.5(1) \times 10^{-7}$ & $2.7(9) \times 10^{-8}$ & $8.65 \times 10^{-9}$ \\
500 & $1.95(1) \times 10^{-7}$ & $6.36(6) \times 10^{-7}$ & $1.96(3) \times 10^{-7}$ & $1.30 \times 10^{-6}$ \\
1000 & $0.88(4) \times 10^{-6}$ & $1.62(6) \times 10^{-6}$ & $2.69(9) \times 10^{-6}$ & - \\
\hline \hline
\end{tabular}

quantitative discussion.

3.2 Influence of lattice size and mobile ion size on $\mathrm{Li}$ ion migration

In $\mathrm{MD}$ simulation, by manipulating the variable conditions, those factors which influence $\mathrm{Li}$ ion conductivity can be independently controlled. In order to understand the relationship between $\mathrm{Li}$ ion conduction and lattice size, we executed MD simulations in which $\mathrm{Li}$ ion size was changed under various pressures and investigated the resulting variations of $\mathrm{Li}$ ion conductivity. In this Section, the simulations were executed under the pressures of 0,10 and $50 \mathrm{GPa}$ with various $a_{\mathrm{Li}}$ values $\left(a_{\mathrm{Li}}=0.0801,0.0851,0.0901,0.0951\right.$, $0.1001,0.1101$ and $0.1201 \mathrm{~nm}$ ) which reflect the radius of $\mathrm{Li}$ ion, and discuss the variation of $D^{\mathrm{Li}}$ for each condition.

Table 4 shows the average interatomic distance of $\mathrm{O}-\mathrm{O}$ ion pair, $r_{\mathrm{O}-\mathrm{O}}$, and $\mathrm{Li}-\mathrm{O}$ ion pair, $r_{\mathrm{Li}-\mathrm{O}}$. The $r_{\mathrm{O}-\mathrm{O}}$ was independent of $a_{\mathrm{Li}}$, but $r_{\mathrm{Li}-0}$ decreased with $a_{\mathrm{Li}}$. Figure 7 shows the variation of the effective radius of $\mathrm{Li}$ ion, $R_{\mathrm{Li}}$, calculated by Eq. (4),

$$
R_{\mathrm{Li}}=r_{\mathrm{Li}-\mathrm{O}}-\frac{1}{2} r_{\mathrm{O}-\mathrm{O}}
$$

As shown in this figure, $R_{\mathrm{Li}}$ decreased linearly with $a_{\mathrm{Li}}$ in the range $a_{\mathrm{Li}} \leq 0.1001$. Therefore we could change the $\mathrm{Li}$ ion size only by changing $a_{\mathrm{Li}}$ while keeping the lattice size constant. The gradual variation of $R_{\mathrm{Li}}$ in $a_{\mathrm{Li}}>0.1001$ was caused by excess size of the $\mathrm{Li}$ ion. In this simulation cell the lattice parameter at $300 \mathrm{~K}$ was about $0.389 \mathrm{~nm}$, and the distance between the oxide ion and the cation at the A-site is calculated at $0.505 \mathrm{~nm}$. Therefore, the $\mathrm{Li}$ ion can not

Table 4. Average Interatomic Distances under Ambient Pressure in MD Simulation

\begin{tabular}{ccc}
\hline \hline \multirow{2}{*}{$a_{\mathrm{Li}}(\mathrm{nm})$} & \multicolumn{2}{c}{ Average interatomic distance } \\
& O-O (nm) & Li-O (nm) \\
\hline 0.0801 & 0.275 & 0.242 \\
0.0851 & 0.275 & 0.244 \\
0.0901 & 0.275 & 0.252 \\
0.0951 & 0.275 & 0.258 \\
0.1001 & 0.275 & 0.264 \\
0.1101 & 0.275 & 0.269 \\
0.1201 & 0.275 & 0.271 \\
\hline \hline
\end{tabular}

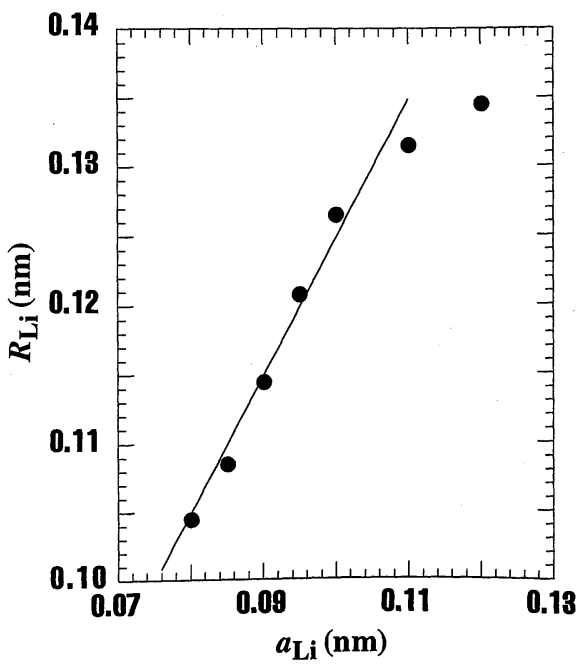

Fig. 7. Variation of effective ionic radius of $\mathrm{Li}$ ion, $R_{\mathrm{Li}}$, with $a_{\mathrm{Li}}$. 
detach freely from $\mathrm{O}$ ions when $R_{\mathrm{Li}} \geq 0.131 \mathrm{~nm}$ and the variation of $R_{\mathrm{Li}}$ in $a_{\mathrm{Li}}>0.1001$ is gradual.

Figure 8 shows the variation of ionic conductivity with $a_{\mathrm{Li}}$ at $1000 \mathrm{~K}$ under various pressures. Under ambient pressure, the ionic conductivity attained a maximum $1.41 \times$ $10^{-2} \mathrm{~S} \cdot \mathrm{cm}^{-1}$ at $a_{\mathrm{Li}}=0.0951$. This compound was found to be the optimum mobile ion size for $\mathrm{Li}$ ion migration. The ionic conductivity at $a_{\mathrm{Li}}=0.0901$ and $a_{\mathrm{Li}}=0.0851$ attained their maximum under $10 \mathrm{GPa}$ and $50 \mathrm{GPa}$, respectively. This suggests that the pressure approaches the framework size in the direction which is more suitable for ion conduction, similarly as in $\mathrm{Li}^{+} \beta-\mathrm{Al}_{2} \mathrm{O}_{3},{ }^{23}$ ) when the mobile ion size is too small for the framework size. When $a_{\mathrm{Li}}$ is $0.0901 \mathrm{~nm}$, the framework size is most suitable under about $10 \mathrm{GPa}$ and contracted to the smaller size than suitable under 50 $\mathrm{GPa}$. The pressure under which the ionic conductivity was maximum increased with $a_{\mathrm{Li}}$ in the range, $0.0851 \leq a_{\mathrm{Li}}$ $\leq 0.0951$ thus the suitable framework size varies with the mobile ion size and this compound seems to have a suitable framework size for each mobile ion size. The effect of pressure for ion conduction disappeared at $a_{\mathrm{Li}}=0.0801$. The change of framework size in this pressure range is not enough to affect ion conduction. A pressure of more than $50 \mathrm{GPa}$ would be required in order to optimize the framework for the $\mathrm{Li}$ ion at $a_{\mathrm{Li}}=0.0801$.

Figure 9 shows the trajectory plots of ions on $\{100\}$ plane at $1000 \mathrm{~K}$ under ambient pressure for $a_{\mathrm{Li}}=0.1201, a_{\mathrm{Li}}$ $=0.0951$, and $a_{\mathrm{Li}}=0.0801$. When $a_{\mathrm{Li}}=0.0951 \mathrm{~nm}$ the $\mathrm{Li}$ ions migrated freely, though they ions tended to stay at the A-site or bottleneck at $a_{\mathrm{Li}}=0.1201$ and 0.0801 . These results were supported by the pair correlation function.

Figure 10 shows the pair correlation function, $g_{\mathrm{Li}-\mathrm{Ti}}(r)$ for $a_{\mathrm{Li}}=0.0801, a_{\mathrm{Li}}=0.0951$, and $a_{\mathrm{Li}}=0.1201$ at $1000 \mathrm{~K}$ under ambient pressure. When $a_{\mathrm{Li}}=0.0801$, the peak was observed at $r_{\mathrm{ij}}=0.27 \mathrm{~nm}$ which is the distance between the $T i$ ion and bottleneck. When $a_{\mathrm{Li}}=0.1201$, the peak was observed at $r_{\mathrm{ij}}=0.34 \mathrm{~nm}$ which is the distance between the $\mathrm{T} i$ ion and the A-site. On the other hand, for $a_{\mathrm{Li}}=0.0951$ the peaks are broadened. These represent that at $a_{\mathrm{Li}}=0.0951$ $\mathrm{Li}$ ions migrate freely in the simulation cell, and at $a_{\mathrm{Li}}$ $=0.1201$ and $a_{\mathrm{Li}}=0.0801 \mathrm{Li}$ ions tend to stay around the Asite and the vicinity of bottleneck, respectively. Figure 11 shows the $g_{\mathrm{Li}-\mathrm{Ti}_{\mathrm{i}}}(r)$ at $1000 \mathrm{~K}$ under ambient pressure and $50 \mathrm{GPa}$ for $a_{\mathrm{Li}}=0.0851$. The $g_{\mathrm{Li}-\mathrm{Ti}}(r)$ under ambient pressure showed that the $\mathrm{Li}$ ion was distributed in the vicini-

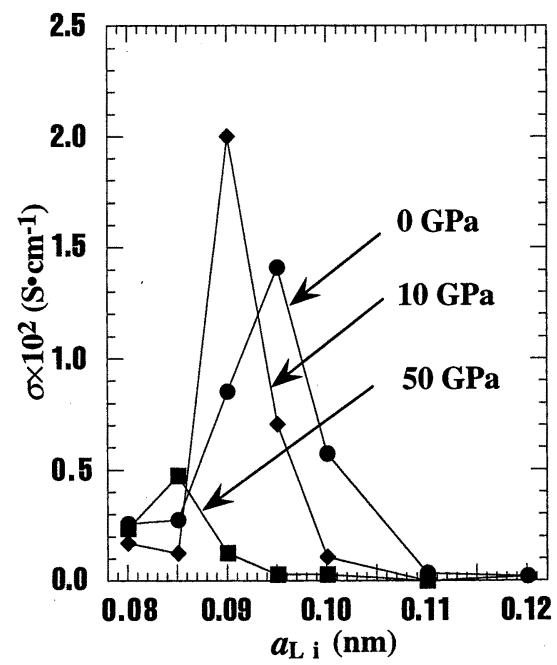

Fig. 8. Variation of ionic conductivity with repulsion parameter of $\mathrm{Li}$ ion, $a_{\mathrm{Li}}$, under ambient pressure, $10 \mathrm{GPa}$, and $50 \mathrm{GPa}$ at $1000 \mathrm{~K}$.
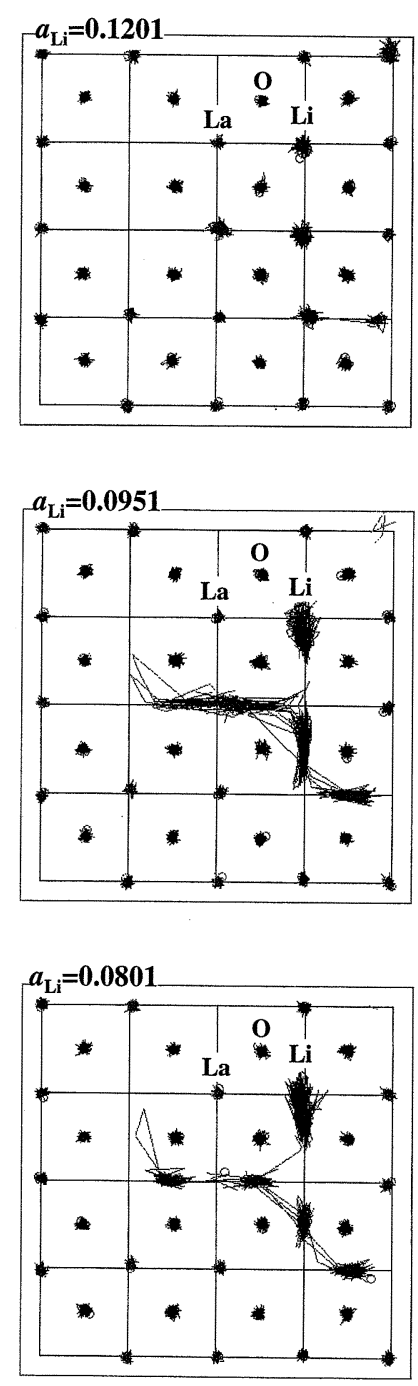

Fig. 9. Trajectory plots of $\mathrm{Li}, \mathrm{La}$ and $\mathrm{O}$ ions projected on $\{100\}$ plane for $\mathrm{La}_{0.6} \mathrm{Li}_{0.2} \mathrm{TiO}_{3}$ at $1000 \mathrm{~K}$ under ambient pressure. Upper plot, middle plot, and lower plot is $a_{\mathrm{Li}}=0.1201 \mathrm{~nm}, a_{\mathrm{Li}}=0.0951 \mathrm{~nm}$ and $a_{\mathrm{Li}}=0.0801 \mathrm{~nm}$, respectively.

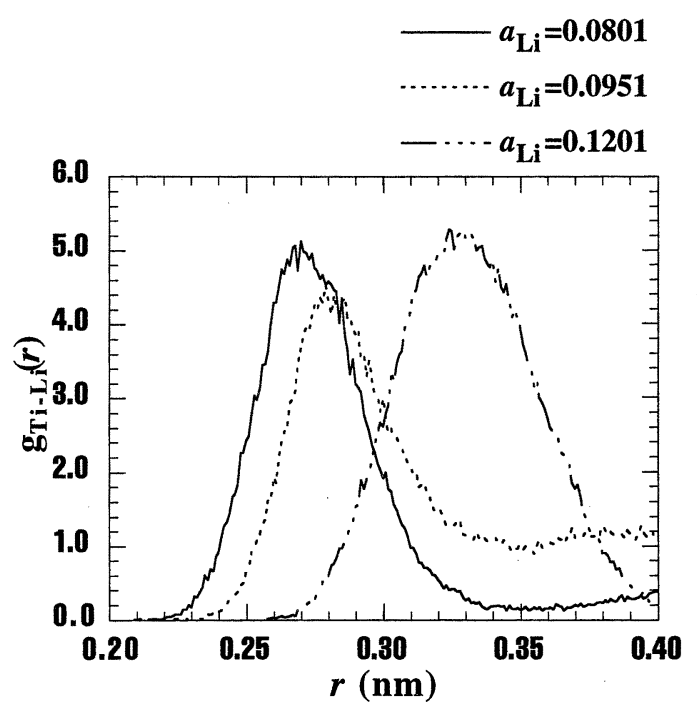

Fig. 10. Pair correlation function between $\mathrm{Li}$ and $\mathrm{Ti}$ ions at $a_{\mathrm{Li}}$ $=0.1201 \mathrm{~nm}, a_{\mathrm{Li}}=0.0951 \mathrm{~nm}$ and $a_{\mathrm{Li}}=0.0801 \mathrm{~nm}$ at $1000 \mathrm{~K}$ under ambient pressure. 


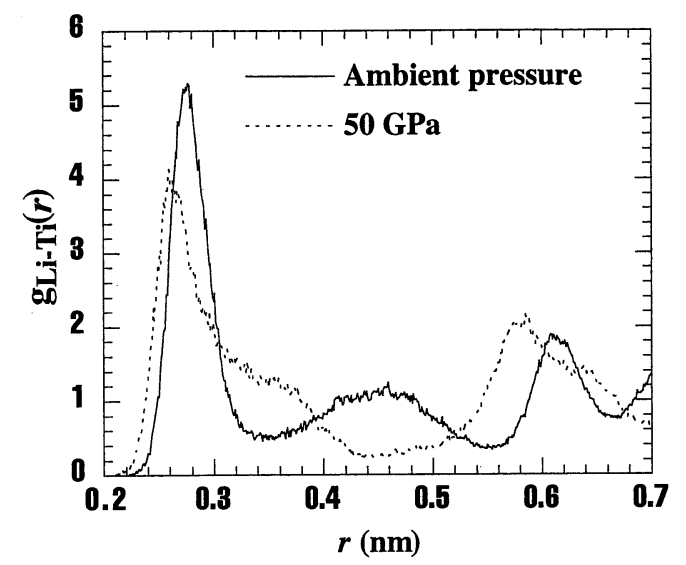

Fig. 11. Pair correlation function between $\mathrm{Li}$ and $\mathrm{Ti}$ ions at $1000 \mathrm{~K}$ under ambient pressure and $50 \mathrm{GPa}\left(a_{\mathrm{Li}}=0.0851 \mathrm{~nm}\right)$.

ty of the bottleneck. Under $50 \mathrm{GPa}$, the peaks were observed at $0.27 \mathrm{~nm}$ and $0.32 \mathrm{~nm}$. The position where $\mathrm{Li}$ ions mainly stay varies from bottleneck to A-site with increasing pressure, because the distance between the B-site and bottleneck and B-site and A-site under $50 \mathrm{GPa}$ are $0.276 \mathrm{~nm}$ and $0.338 \mathrm{~nm}$, respectively. These results imply that in this simulation the decrease in $a_{\mathrm{Li}}$ has the same effect on the ion conduction as the lattice expansion.

When $a_{\mathrm{Li}}=0.1201 \mathrm{~nm}, \mathrm{Li}$ ions wander around the A-site, and few $\mathrm{Li}$ ions migrate through the bottleneck due to its large size. When mobile ion size is too large for the framework size, the ion can not migrate through the bottleneck and the ion conductivity decreases for this compound. When $a_{\mathrm{Li}}=0.0801 \mathrm{~nm}, \mathrm{Li}$ ions stayed around the bottleneck and migrated from bottleneck to bottleneck without passing the A-site. The potential at bottleneck and A-site are found to increase and decrease with decreasing $a_{\mathrm{Li}}$, respectively. Stabilizing the potential for $\mathrm{Li}$ ion at the bottleneck by decreasing $a_{\mathrm{Li}}$ is reasonable, because the short range repulsion decreases with decreasing $a_{\mathrm{Li}}$. The increase in the potential energy at the A-site with the lattice expansion was suggested by the energetic calculation. ${ }^{13)}$ Inaguma et al. reported that the potential energy around the A-site increases with an increase in the lattice parameter, and that the lowest energy path gradually swerves from the A-site. ${ }^{13)}$ Since the lattice expansion has the same effect on $\mathrm{Li}$ ion migration as the decrease in $a_{\mathrm{Li}}$ in this simulation, the decrease in ion conductivity is considered to be due to the interruption of the ion conduction at the A-site when mobile ion size is excessively small.

3.3 Estimation of $\mathrm{Li}$ ion conductivity in the optimized structure

The optimum lattice size for $\mathrm{Li}$ ion conduction is an important information for the design of new $\mathrm{Li}$ ion conductors. In this Section we estimated the optimum lattice size and $\mathrm{Li}$ ion conductivity in the optimized structure using MD simulation.

Figure 12 shows the variation of ionic conductivity with the lattice parameter, $a_{\mathrm{p}}$, at $1000 \mathrm{~K}$. In this case, $a_{\mathrm{Li}}$ was fixed to 0.0901 because $\mathrm{Li}$ ion conductivity apparently attains a maximum in the pressure range between 0 and 50 $\mathrm{GPa}$ when $a_{\mathrm{Li}}=0.0901 \mathrm{~nm}$. As shown in this figure, at $a_{\mathrm{p}}$ $=0.3799 \mathrm{Li}$ ion conductivity attained a maximum value, 4.5 $\times 10^{-2} \mathrm{~S} \cdot \mathrm{cm}^{-1}$, which was about 3 times higher than that reproduced physical properties. The $R_{\mathrm{Li}}$ at $a_{\mathrm{Li}}=0.0901$ is estimated as $0.120 \mathrm{~nm}$ in Fig. 7, and the ionic radius of the $\mathrm{Li}$ ion for coordination 12 is estimated to within $0.125 \mathrm{~nm}$ by extrapolation of the variation of ionic radius of the coordination number ${ }^{32}$ If the ionic radius of the $\mathrm{Li}$ ion in the ac-

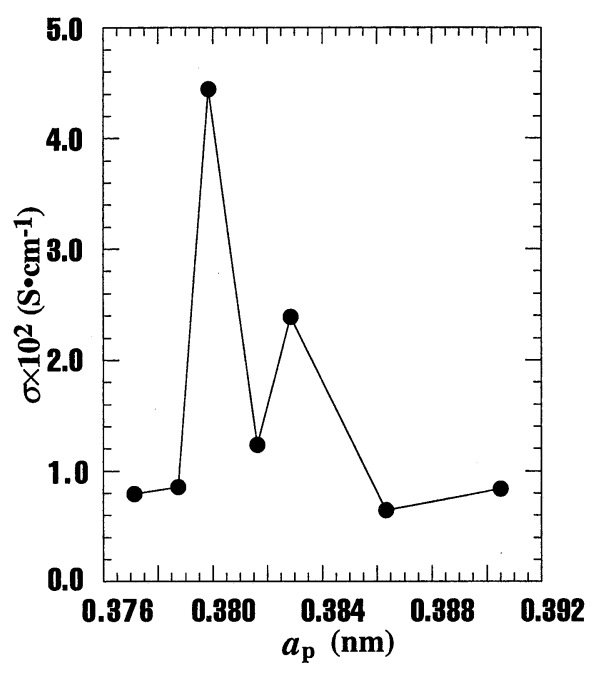

Fig. 12. Variation of perovskite parameter, $a_{\mathrm{p}}$, with ionic conductivity, $\sigma$, for $a_{\mathrm{Li}}=0.0901 \mathrm{~nm}$ at $1000 \mathrm{~K}$.

tual $\mathrm{La}_{0.6} \mathrm{Li}_{0.2} \mathrm{TiO}_{3}$ assumes $0.125 \mathrm{~nm}$, the optimum bottleneck size predicted by this simulation study is $0.412 \mathrm{~nm}$. This value is larger than the actual $\mathrm{La}_{0.6} \mathrm{Li}_{0.2} \mathrm{TiO}_{3}\left(a_{\mathrm{p}}\right.$ $=0.3877 \mathrm{~nm})$. By the extrapolation of the relationship between $a_{\mathrm{p}}$ and the activation energy, $E_{\mathrm{a}}$, for $\mathrm{Ln}_{0.5} \mathrm{Li}_{0.5} \mathrm{TiO}_{3}$ $(\mathrm{Ln}=\mathrm{La}, \mathrm{Pr}, \mathrm{Nd}, \mathrm{Sm})^{11)-13)}$ to $E_{\mathrm{a}}=0$, the optimum lattice parameter is calculated as $0.3945 \mathrm{~nm}$. This value is in good agreement with that predicted by this $\mathrm{MD}$ simulation. Consequently, it is indicated that $\mathrm{La}_{0.6} \mathrm{Li}_{0.2} \mathrm{TiO}_{3}$ has an optimum bottleneck size and that ionic conductivity increases by the optimization of the crystal structure.

\section{Conclusions}

The simulation using the PIM could simultaneously reproduce the crystal structure at room temperature and its physical properties (thermal expansion, compressibility, and $\mathrm{Li}$ ion migration). But $\mathrm{Li}$ ion conductivity could not be reproduced quantitatively due to the insufficient number of calculation steps and/or simulation cells. The observation of $\mathrm{Li}$ ion motion using MD simulation for various $a_{\mathrm{Li}}$ under high pressure revealed that the decrease in $\mathrm{Li}$ ion conductivity with lattice contraction and lattice expansion was due to the interruption of $\mathrm{Li}$ ion migration at the bottleneck and at the A-site, respectively. According to the investigation of $\mathrm{Li}$ ion conductivity at various lattice sizes, $\mathrm{Li}$ ion conductivity at $1000 \mathrm{~K}$ attained $4.5 \times 10^{-2} \mathrm{~S} \cdot \mathrm{cm}^{-1}$ at $a_{\mathrm{p}}=0.3799$ when $a_{\mathrm{Li}}$ was $0.0901 \mathrm{~nm}$. This value was 3 times larger than that of the simulation using parameters reproducing physical properties. Furthermore, the suitable lattice size predicted by MD simulation was $0.412 \mathrm{~nm}$, which is larger than the actual lattice parameter, $0.3877 \mathrm{~nm}$, of $\mathrm{La}_{0.6} \mathrm{Li}_{0.2}$ $\mathrm{TiO}_{3}$. These simulations indicated that $\mathrm{La}_{0.6} \mathrm{Li}_{0.2} \mathrm{TiO}_{3}$ has an optimum lattice size, and that the ionic conductivity becomes several times higher by extending the framework structure.

Acknowledgments Part of this work was supported by JSPS Research for the "Atomic-Scale Surface and Interface Dynamics" program, and by a Grand-in-Aid for Scientific Research from the Ministry of Education, Science, and Culture. Special thanks are also due to Dr. Dae-Weon Kim for his many useful suggestions.

\section{References}

1) H. Aono, E. Sugimoto, Y. Sadaoka, N. Imanaka and G. Adachi, J. Electrochem. Soc., 140, 1827-33 (1993).

2) J. Kennedy and Z. Zhang, J. Electrochem. Soc., 135, 859-62 (1988). 
3) J. Fu, Solid State Ionics, 96, 195-200 (1997).

4) Y. Inaguma, Y. Matsui, Y. J. Shan, M. Itoh and T. Nakamura, Solid State Ionics, 79, 91-97 (1995).

5) A. G. Belous, G. N. Novitiskaya, S. V. Polyanetskaya and Y. I. Gornikov, Izv. Akad. Nauk SSSR, Neorg. Mater., 23, 47072 (1987).

6) Y. Inaguma, L. Chen, M. Itoh, T. Nakamura, T. Uchida, M. Ikuta and M. Wakihara, Solid State Commun., 86, 689-93 (1993).

7) Y. Inaguma, L. Chen, M. Itoh and T. Nakamura, Solid State Ionics, 70/71, 196-202 (1994).

8) Y. Inaguma and M. Itoh, Solid State Ionics, $86-88,257-60$ (1996).

9) T. Katsumata, Y. Matsui, Y. Inaguma and M. Itoh, Solid State Ionics, 86-88, 165-69 (1996).

10) Y. Inaguma, Y. Matsui, J. Yu and M. Itoh, Mater. Res. Soc. Symp. Proc., 453 (1997) pp. 623-28.

11) M. Itoh, Y. Inaguma, W. H. Jung, L. Chen and T. Nakamura, Solid State Ionics, 70/71, 203-07 (1994).

12) Y. Inaguma, J. Yu, Y. J. Shan, M. Itoh and T. Nakamura, J. Electrochem. Soc., 142, L8-11 (1995).

13) Y. Inaguma, Y. Matsui, J. Yu, Y. J. Shan, M. Itoh and T. Nakamura, J. Phys. Chem. Solids, 58, 843-52 (1997).

14) J. S. Lee, K. W. Yoo, T. S. Kim and H. J. Jung, Solid State Ionics, 98, 15-26 (1997).

15) C. Léon, M. L. Lucía, J. Santamaría, M. A. París, J. Sanz and A. Váres, Phys. Rev., B54, 184-89 (1996).

16) C. Léon, J. Santamaría, M. A. París, J. Sanz, J. Ibarra, L. M. Torres and A. Váres, Phys. Rev., B56, 5302-05 (1997).

17) C. Léon, M. L. Lucía, J. Santamaría and F. Sánches-Quesada,
Phys. Rev., B57, 41-47 (1998)

18) J. L. Fourquet, H. Duroy and M. P. Crosnier-Lopez, J. Solid State Chem., 127, 283-94 (1996).

19) A. D. Robertson, S. G. Martin, A. Coats and A. R. West, J. Mater. Chem., 5, 1405-12 (1995).

20) P. Birke, S. Scharner, R. A. Huggins and W. Weppner, J. Electrochem. Soc., 144, L167-69 (1997).

21) M. Oguni, Y. Inaguma, M. Itoh and T. Nakamura, Solid State Commun., 91 627-30 (1994).

22) Y. F. Yao and J. T. Kummer, J. Inorg. Nucl. Chem., 29, 2453-75 (1967)

23) R. H. Radzilowski and T. Kummer, J. Electrochem. Soc., 118, 714-16 (1971).

24) K. Itoh, K. Kondo, A. Sawaoka and S. Saitoh, Jpn. J. Appl. Phys., 14, 1237-39 (1975).

25) K. Kawamura, Proc. the 13th Taniguchi Sym., Kashikojima Japan, No. 6-9 (1990) pp. 87-97.

26) R. Courths, B. Cord and H. Saalfeld, Solid State Commun., 70, 1047-51 (1989)

27) K. Takegahara, J. Electron Spectros. Relat. Phenom., 66, 30320 (1994).

28) D. W. Kim, N. Enomoto, Z. Nakagawa and K. Kawamura, J. Am. Ceram. Soc., 79, 1095-99 (1996).

29) L. Pauling, "The Nature of Chemical Bond," Cornell University Press, New York (1960).

30) K. Kawamura, MXDORTO, Japan Chemistry Program Exchange, \#029.

31) L. R. Edwards and R. W. Lynch, J. Phys. Chem. Solids, 31, 573-74 (1970).

32) R. D. Shannon, Acta Cryst., A32, 751 (1976). 